Revista Eletrônica de Direito Processual - REDP.

Rio de Janeiro. Ano 16. Volume 23. Número 1. Janeiro a Abril de 2022

Periódico Quadrimestral da Pós-Graduação Stricto Sensu em Direito Processual da UERJ

Patrono: José Carlos Barbosa Moreira (in mem.). ISSN 1982-7636. pp. 1266-1295

www.redp.uerj.br

\title{
A (IN)APLICABILIDADE DA MEDIAÇÃO EM LITÍGIOS FAMILIARES QUE ENVOLVAM MULHERES EM SITUAÇÃO DE VIOLÊNCIA DOMÉSTICA ${ }^{1}{ }^{2} 2$
}

\author{
NON-APPLICABILITY OF MEDIATION TO SETTLE FAMILY DISPUTES \\ INVOLVING WOMEN VICTIMS OF DOMESTIC VIOLENCE AND ABUSE
}

Renata Helena Paganoto Moura

Doutoranda em Direito pela Faculdade de Direito de Vitória (FDV), Mestre em Direito pela PUC/SP. Professora do curso de Direito da graduação e da pós-graduação da Faculdade de Direito de Vitória (FDV). Advogada e Sócia do Escritório Mediação \& Advocacia. Coordenadora da Câmara Brasileira de Mediação e Arbitragem Empresarial em Campo Limpo Paulista - $\quad$ SP. $\quad$ Vitória/ES. E-mail: renata@mediacaoeadvocacia.com.br.

Alexandre de Castro Coura Pós-doutorado como visiting scholar na American University e visiting foreign judicial fellow no Centro Judiciário Federal em Washington D.C. Doutor e Mestre em Direito Constitucional pela Universidade Federal de Minas Gerais (UFMG). Professor de Teoria dos Direitos Fundamentais no Programa de Mestrado e Doutorado da Faculdade de Direito de Vitória (FDV). Promotor de Justiça no Espírito Santo. Vitória/ES. E-mail: acastrocoura@gmail.com.

\footnotetext{
${ }^{1}$ Artigo recebido em 17/04/2021 e aprovado em 23/11/2021.

${ }^{2}$ Este artigo é resultado das atividades do Grupo de Pesquisa Hermenêutica Jurídica e Jurisdição Constitucional vinculado ao programa de pós-graduação strictu sensu da Faculdade de Direito de Vitória e registrado no diretório CNPQ (http://dgp.cnpq.br/dgp/espelhogrupo/15188).
} 


\title{
Marina Roldi Herkenhoff
}

Pós-graduada em Direito de Família e graduada em direito pela Faculdade de Direito de Vitória (FDV). Advogada. Vitória/ES. E-Mail: marinaroldih@gmail.com.

RESUMO: O presente artigo busca analisar a (im)possibilidade de aplicação do método da mediação em conflitos familiares que envolvam mulheres em situação de violência doméstica. A partir do estudo de conceitos, contextos e efeitos da violência doméstica, bem como de princípios e requisitos da mediação, utilizando-se do método dialético e da técnica documental, o trabalho analisa a obrigatoriedade da mediação para conflitos familiares que envolvam mulheres vítimas de violência doméstica e sugere uma interpretação constitucional do art. 27 da Lei de Mediação e do art. 695 do CPC para o fim de garantir a dignidade humana dessas mulheres.

PALAVRAS-CHAVE: Mediação; métodos alternativos de solução de conflitos; conflitos familiares; violência doméstica; interpretação constitucional.

\begin{abstract}
The objective of this paper was to analyze whether or not the method of mediation of family disputes involving women abuse in a domestic setting can be applied. In order to address the issue, the research used the dialectical method and document analysis technique. From the study of concepts, contexts, and effects of domestic violence, along with the principles and requirements of mediation, this study examines the compulsory application of mediation in family disputes involving abused and battered women and proposes a constitutional interpretation of art. 27 of the Mediation Law and art. 695 of the CPC in order to guarantee these women dignity.
\end{abstract}

KEYWORDS: Mediation; alternative dispute resolution; family disputes; domestic abuse; constitutional interpretation. 


\section{INTRODUÇÃO}

O trato de mulheres em situação de violência doméstica pelo poder público é um tema extremamente necessário para a comunidade acadêmica em razão da falta de respaldo jurídico que permeia o assunto, bem como em decorrência das falhas históricas que o Estado tem causado a essas mulheres devido ao despreparo para lidar com a problemática.

Mulheres que vivem em situação de violência doméstica estão em um contexto incontestavelmente vulnerável, e necessitam do devido amparo do poder estatal para que sua segurança, saúde, integridade física e psíquica sejam resguardadas. $\mathrm{O}$ amparo estatal, nesse caso, é pressuposto para a garantia do próprio direito à vida dessas mulheres.

Como cidadãs, possuem direito a que o tratamento da situação junto ao poder público seja feito de forma peculiar e atenta, sendo que a aplicação de regras genéricas, mesmo que procedimentais, pode ser extremamente danosa à dignidade da mulher que sofre com a violência intrafamiliar.

Tudo isso pode ocasionar uma revitimização dessa pessoa por meio da violência institucional que ela sofrerá em razão do despreparo do judiciário e da insegurança quanto à garantia de seus direitos ${ }^{3}$, o que além de causar um sentimento de frustração e desamparo nas vítimas, também retira credibilidade do poder público.

Nesse contexto buscamos analisar se é possível aplicar a exigência da realização da audiência de mediação prevista pela legislação cível (art. 27 da Lei de Mediação e art. 695, caput, do CPC), para litígios familiares que envolvam mulheres em situação de violência doméstica.

O processo judicial sempre foi tradicionalmente o método de resolução para conflitos familiares. Entretanto, consiste em um procedimento que logo de início coloca as partes em confronto, na condição de autor e réu que se enfrentam, sendo que as soluções são entregues por um terceiro imparcial e alheio à controvérsia familiar. Os métodos adequados de

\footnotetext{
${ }^{3}$ CHAI, Cássius Guimarães; SANTOS, Jéssica Pereira dos; CHAVES, Denisson Gonçalves. Violência institucional contra a mulher: o poder judiciário, de pretenso protetor a efetivo agressor. Revista Eletrônica do Curso de Direito da UFSM, Santa Maria, RS, v. 13, n. 2, p. 640-665, ago. 2018. ISSN 1981-3694. Disponível em: https://periodicos.ufsm.br/revistadireito/article/view/29538. Acesso: 23/12/2019.
} 
Revista Eletrônica de Direito Processual - REDP.

Rio de Janeiro. Ano 16. Volume 23. Número 1. Janeiro a Abril de 2022

Periódico Quadrimestral da Pós-Graduação Stricto Sensu em Direito Processual da UERJ

Patrono: José Carlos Barbosa Moreira (in mem.). ISSN 1982-7636. pp. 1266-1295

www.redp.uerj.br

resolução de conflitos, por sua vez, se apresentam de forma privilegiada para a solução dos conflitos familiares, isso porque são métodos que priorizam soluções não-adversariais, por darem protagonismo às próprias partes envolvidas diretamente na controvérsia.

A mediação, por suas características, se apresenta como o método adequado por excelência para o direito de família.

Por esse motivo, a lei processual civil prevê até mesmo procedimento especial para os casos familiares, determinando que nas ações de família, todos os esforços serão empreendidos para a solução consensual da controvérsia (art. 694 do CPC), bem como estabelecendo a designação imediata da audiência de mediação/conciliação após o recebimento da petição inicial, no art. 695 do Código de Processo Civil. Também o art. 27 da Lei de mediação faz a mesma determinação.

Tal previsão não é uma mera formalidade, mas uma necessidade para o trato do direito de família na justiça brasileira, considerando que as questões de família são o ramo mais sensível do direito, que demandam tutela diferenciada e especializada, com tratamento individualizado, sob pena de prejudicar o contexto familiar inserido na lide ${ }^{4}$, sendo essencial a realização da mediação nesses casos.

O uso dos meios adequados de resolução de conflitos no trato das questões familiares, como a mediação, é imprescindível porque demonstra aos envolvidos uma característica positiva do conflito, que é a de oferecer um potencial criativo capaz de auxiliar as famílias a redefinir sua identidade por meio de mudanças e adaptações diante da situação ocasionada pela controvérsia, uma vez que a possibilidade de diálogo apresentada por esses métodos é capaz de oferecer o reconhecimento da pessoa, bem como uma solução não-violenta do conflito ${ }^{5}$.

Mas associar essas características do método ao conflito familiar e daí necessariamente concluir que a mediação é sempre o método adequado, é deixar de analisar

\footnotetext{
${ }^{4}$ DIAS, Maria Berenice. Manual de direito das famílias. 12. ed. São Paulo: Editora Revista dos Tribunais, 2017, p. 75.

${ }^{5}$ ALMEIDA, Guilherme Assis de. Mediação e o Reconhecimento da Pessoa. Revista do Advogado. São Paulo, v. ano XXXIV, n. 123, p. 19-23, ago., 2014, p. 20.
} 
Revista Eletrônica de Direito Processual - REDP.

Rio de Janeiro. Ano 16. Volume 23. Número 1. Janeiro a Abril de 2022

Periódico Quadrimestral da Pós-Graduação Stricto Sensu em Direito Processual da UERJ

Patrono: José Carlos Barbosa Moreira (in mem.). ISSN 1982-7636. pp. 1266-1295

www.redp.uerj.br

outras perspectivas desse conflito, principalmente quando a mulher está submetida a uma situação de violência doméstica.

Em razão disso, a análise do conflito familiar deve ser feita com muita atenção pelas pessoas que atuarão em sua solução para identificar se a mediação será o método adequado ou se no caso concreto apenar irá reforçar uma situação de vulnerabilidade.

\section{MEDIAÇÃO COMO MÉTODO ADEQUADO DE RESOLUÇÃO DE CONFLITOS FAMILIARES E ACESSO À JUSTIÇA}

O processo civil está passando por uma transformação no que diz respeito aos métodos de resolução de conflitos submetidos à justiça: ao contrário de uma justiça estatal clássica, de porta única, a justiça atual se mostra como uma justiça multiportas, com novas formas de acesso $^{6}$.

Neste cenário de justiça multiportas, onde se trabalha com a ideia de método adequado para solução do conflito, a justiça não-estatal deixa de ser apenas 'alternativa' para em muitos casos ser a justiça adequada. Por isso, há muito se abandonou a ideia de "métodos alternativos", porque tais métodos não são alternativos ou secundários ao processo judicial, mas os métodos legítimos e adequados.

Contudo, essa tendência recente é uma conquista, consequência de uma realidade que carrega o peso da excessiva judicialização dos conflitos. A insistente procura pelo judiciário, como já apontava Mancuso, é um comportamento inserido no contexto de uma cultura demandista ou judiciarista, que reflete uma tendência à judicialização dos conflitos, a qual ocorre, entre outros motivos, por uma resistência ou desconhecimento de outros métodos de resolução de conflitos além do judicial, que se sustenta no falso ideal do monopólio estatal na distribuição da justiça. ${ }^{7}$

\footnotetext{
${ }^{6}$ DIDIER JR, Fredie; ZANETI JR, Hermes. Justiça Multiportas e tutela adequada em litígios complexos: a autocomposição e os direitos coletivos. In: ZANETI JR, Hermes; CABRAL, Trícia Navarro Xavier (Coord.). Justiça Multiportas: mediação, conciliação, arbitragem e outros meios adequados de solução de conflitos. Salvador: Juspodivm, 2018, p. 38.

7 MANCUSO, Rodolfo de Camargo. A resolução dos conflitos e a função judicial no contemporâneo Estado de Direito. São Paulo: Editora Revista dos Tribunais, 2009, p. 11.
} 
Revista Eletrônica de Direito Processual - REDP.

Rio de Janeiro. Ano 16. Volume 23. Número 1. Janeiro a Abril de 2022

Periódico Quadrimestral da Pós-Graduação Stricto Sensu em Direito Processual da UERJ

Patrono: José Carlos Barbosa Moreira (in mem.). ISSN 1982-7636. pp. 1266-1295

www.redp.uerj.br

Em outras palavras, há quem acredite que o acesso à justiça, consagrado no art. $5^{\circ}$, inciso XXXV da Constituição Federal de 1988, somente tome forma quando for possível submeter a demanda ao judiciário, consagrando o referido monopólio estatal na distribuição da justiça.

Contudo, fica evidente que o acesso à justiça não é o acesso ao Judiciário para obtenção de uma solução trazida por sentença, mas é o acesso a uma "ordem jurídica justa", que se dá por meio do alcance de técnicas e procedimentos adequados para a solução do conflito, que possam efetivamente sanar a demanda e garantir o cumprimento do direito material compreendido na disputa em questão.

A excessiva judicialização dos conflitos, como aponta Nalini, caminha fatalmente para o esgotamento do sistema, que se mostra na prática pela morosidade da estrutura judiciária no Brasil, tornando o processo judicial um dos meios menos eficientes para garantir uma resposta tempestiva e efetiva para determinadas demandas. ${ }^{9}$

Assim, a importância da autocomposição se mostra devido à sua contribuição para o "desafogamento" processual do judiciário, sendo um método mais célere, e devido ao seu potencial de proporcionar soluções mais adequadas e efetivas para os conflitos apresentados. Muitas vezes, a abordagem judicial impede que sejam tratadas questões que só poderiam ser resolvidas de forma satisfatória mediante uma solução construída consensualmente entre as partes. Isso porque o processo judicial possui grande cunho de impessoalidade.

Nesses casos, é certo que uma decisão imposta por um terceiro não resolve de fato os reais interesses e causas do conflito, apenas trata de pleitos das partes que refletem sua posição exteriorizada em um pedido objetivo na parte dispositiva de uma petição, sendo raros os casos de ganhos mútuos para os envolvidos, causando maior insatisfação.

\footnotetext{
${ }^{8}$ WATANABE, Kazuo. Acesso à justiça e solução pacífica dos conflitos de interesses. In: ZANETI JR, Hermes; CABRAL, Trícia Navarro Xavier (Coord.). Justiça Multiportas: mediação, conciliação, arbitragem e outros meios adequados de solução de conflitos. Salvador: Juspodivm, 2018, p. 840.

${ }^{9}$ NALINI, José Renato. É urgente construir alternativas à justiça. In: ZANETI JR, Hermes; CABRAL, Trícia Navarro Xavier (Coord.). Justiça Multiportas: mediação, conciliação, arbitragem e outros meios adequados de solução de conflitos. Salvador: Juspodivm, 2018, p. 30.
} 
Revista Eletrônica de Direito Processual - REDP.

Rio de Janeiro. Ano 16. Volume 23. Número 1. Janeiro a Abril de 2022

Periódico Quadrimestral da Pós-Graduação Stricto Sensu em Direito Processual da UERJ

Patrono: José Carlos Barbosa Moreira (in mem.). ISSN 1982-7636. pp. 1266-1295

www.redp.uerj.br

O ponto principal para se compreender um conflito em sua totalidade e atingir sua resolução é entender a distinção entre "posições" e "interesses". ${ }^{10}$ Para se chegar a uma solução sensata, devem ser conciliados os interesses das partes, e não suas posições, uma vez que os interesses são o que define o problema, e que por trás de posições opostas há interesses comuns e compatíveis. ${ }^{11}$ Dessa forma, há enorme vantagem em buscar explorar os interesses existentes por trás das posições.

Apesar disso, o que leva as pessoas a recorrem ao judiciário são conflitos de posições opostas, uma vez que as posições são a parcela externalizada do conflito, pois tendem a ser concretas e explícitas, ou seja, são mais tangíveis, e por isso são a parcela do conflito que tende a ser explorada no contexto da judicialização da controvérsia. Por outro lado, os interesses por trás das posições podem ser não-expressos e intangíveis e, por isso, acabam não sendo alcançados dentro da estrutura judicial, o que prejudica o alcance de uma solução efetiva e satisfatória para as partes envolvidas. ${ }^{12}$

Por outro giro, a exploração de interesses reais das partes permite o alcance de soluções e acordos que de fato tenham o condão de resolver a controvérsia com efetividade, o que na maioria das vezes não ocorre com o processo judicial, considerando que este comporta procedimentos e rituais próprios, e uma estrutura congelada/rígida que limita a atividade cognitiva do juiz.

Assim, é possível concluir que os métodos adequados como a mediação e a conciliação resolvem a controvérsia de maneira mais pontual e particular, e, consequentemente, mais justa e efetiva ${ }^{13}$, por explorarem inclusive interesses não-expressos das partes.

A mediação é sempre apontada como o método adequado por excelência a ser aplicado aos conflitos familiares. Isso porque sua atenção não é no conflito em si, mas em

\footnotetext{
${ }^{10}$ FISCHER, Roger; URY, William; PATTON, Bruce. Como chegar ao sim: negociação de acordos sem concessões. $2^{a}$ ed. rev. e ampl. Rio de Janeiro: Imago Ed., 1994, p. 58.

${ }^{11}$ Idem, p. 58-60.

12 FISCHER, Roger; URY, William; PATTON, Bruce. Como chegar ao sim: negociação de acordos sem concessões. $2^{\text {a }}$ ed. rev. e ampl. Rio de Janeiro: Imago Ed., 1994, p. 60.

${ }^{13}$ CABRAL, Trícia Navarro Xavier. Análise comparativa entre a Lei de Mediação e o CPC/2015. In: ZANETI JR, Hermes; CABRAL, Trícia Navarro Xavier (Coord.). Justiça Multiportas: mediação, conciliação, arbitragem e outros meios adequados de solução de conflitos. Salvador: Juspodivm, 2018, p. 473.
} 
Revista Eletrônica de Direito Processual - REDP.

Rio de Janeiro. Ano 16. Volume 23. Número 1. Janeiro a Abril de 2022

Periódico Quadrimestral da Pós-Graduação Stricto Sensu em Direito Processual da UERJ

Patrono: José Carlos Barbosa Moreira (in mem.). ISSN 1982-7636. pp. 1266-1295

www.redp.uerj.br

suas causas ${ }^{14}$ e, portanto, o foco migra do indivíduo para suas relações, sendo uma abordagem sistêmica que tem uma compreensão integrada e complementar do indivíduo junto ao seu contexto familiar e sociocultural ${ }^{15}$.

Isso quer dizer que a mediação não trabalha somente a parte do conflito que se evidencia (posições), mas adentra o conflito para analisar suas causas e o contexto em que os envolvidos estão inseridos (interesses), explorando a relação interpessoal existente e incentivando a interação dos mediados.

A mediação começou a se desenvolver justamente diante de lacunas do judiciário no enfrentamento de questões relativas à separação conjugal, que deram causa à busca por novas estratégias de intervenção adaptadas às necessidades de casais em via de separação ${ }^{16}$.

A técnica se apresenta como uma nova forma de tratar o conflito familiar para além da justiça clássica ${ }^{17}$ sendo uma perspectiva de gestão de conflito mais cooperativa e comunicacional, com espaço ampliado para o diálogo, dando maior credibilidade aos envolvidos e às suas experiências, bem como à sua capacidade e responsabilidade para resolver conjuntamente seus conflitos e diferenças ${ }^{18}$. Dessa forma, por meio de desenvolvimento e incentivo comunicacional, visa priorizar a qualidade da relação interpessoal após o fim da relação conjugal ${ }^{19}$, com maneiras mais democráticas e humanas de se comunicar e relacionar ${ }^{20}$.

No que tange aos efeitos da mediação familiar, as vantagens são confirmadas através de estudos norte-americanos, nos quais restou comprovado que $76 \%$ das mulheres e $62 \%$ dos

\footnotetext{
${ }^{14}$ NEVES, Daniel Amorim Assumpção. Manual de direito processual civil. 11. ed. Salvador: Ed. JusPodivm, 2019 , p. 65.

${ }^{15}$ VICENTE, Reginandréa Gomes. Ressonâncias Pessoais na mediação em crime de gênero e família. Revista do Advogado. São Paulo, v. ano XXXIV, n. 123, p. 90-95, ago., 2014, p. 93.

${ }^{16}$ AVILA, Eliedite Mattos. Mediação familiar: mitos, realidades e desafios. In: WALD, Arnoldo. Arbitragem e mediação: mediação e outros modos alternativos de solução de conflitos. Coleção doutrinas essenciais, v. 6. 1. ed. São Paulo: Editora Revista dos Tribunais, 2014, p. 553.

${ }^{17}$ Idem, p. 553-554.

${ }^{18}$ Idem, p. 554-555

${ }^{19}$ Idem.

${ }^{20}$ Idem, p. 570.
} 
Revista Eletrônica de Direito Processual - REDP.

Rio de Janeiro. Ano 16. Volume 23. Número 1. Janeiro a Abril de 2022

Periódico Quadrimestral da Pós-Graduação Stricto Sensu em Direito Processual da UERJ

Patrono: José Carlos Barbosa Moreira (in mem.). ISSN 1982-7636. pp. 1266-1295

www.redp.uerj.br

homens que passaram pela mediação reconheceram a melhora na comunicação interpessoal $^{21}$.

Em relação aos acordos realizados na mediação, foi constatado o índice de $50 \%$ a $85 \%$ de casais satisfeitos com a solução, sendo que $80 \%$ dos acordos são efetivamente respeitados conforme se estabeleceu na sessão de mediação, e esse resultado é atribuído à voluntariedade e engajamento direto dos mediados que tomaram a decisão em conjunto ${ }^{22}$.

Conforme a Lei 13.140/15, a mediação pode ser extrajudicial, caso em que não demanda envolvimento do Poder Judiciário, ou judicial, caso em que é designada após o recebimento da inicial, conforme os arts. 334, 694, parágrafo único e 695, todos do CPC. Em ambos os casos, a mediação é guiada por um terceiro mediador, escolhido pelas partes ou designado pelo tribunal, e conduzirá o procedimento de comunicação entre os envolvidos, buscando o entendimento e o consenso, e facilitando a resolução do conflito, nos termos do art. $4^{\circ}$, caput e $\S 1^{\circ}$ da Lei de Mediação.

Assim, na hipótese de ser judicial, mesmo que se dê no seio de um processo judicial, a mediação também trará protagonismo às partes para que construam uma solução conjunta para a lide, uma vez que o mediador não poderá impor uma decisão como faria o magistrado, se limitando a conduzir o procedimento para fomentar o diálogo e facilitar a busca por uma solução satisfatória.

De fato, por proporcionar a construção de soluções conjuntas e mais efetivas e fomentar o diálogo entre partes que possuem uma relação continuada e complexa, a técnica de mediação se mostra como um método de resolução de conflito não somente aplicável, mas necessário ao procedimento judicial de conflitos familiares, e por isso é colocada como obrigatória na lei, no art. 27 da Lei 13.140/15 (Lei de Mediação), que determina que o juiz designe audiência de mediação. O caput do art. 695 do CPC também evidencia a obrigatoriedade da mediação nos litígios de família.

\footnotetext{
${ }^{21}$ Idem, p. 568.

${ }^{22}$ AVILA, Eliedite Mattos. Mediação familiar: mitos, realidades e desafios. In: WALD, Arnoldo. Arbitragem e mediação: mediação e outros modos alternativos de solução de conflitos. Coleção doutrinas essenciais, v. 6. 1. ed. São Paulo: Editora Revista dos Tribunais, 2014, p. 568.
} 
Revista Eletrônica de Direito Processual - REDP.

Rio de Janeiro. Ano 16. Volume 23. Número 1. Janeiro a Abril de 2022

Periódico Quadrimestral da Pós-Graduação Stricto Sensu em Direito Processual da UERJ

Patrono: José Carlos Barbosa Moreira (in mem.). ISSN 1982-7636. pp. 1266-1295

www.redp.uerj.br

Assim, o art. 27 da Lei de Mediação e o art. 695 do CPC emitem na opinião de alguns um comando ao juiz, o qual deve seguir a determinação legal e providenciar a realização da sessão de mediação, não permitindo qualquer discricionariedade, por se tratar de norma cogente e obrigatória. ${ }^{23}$

Contudo, apesar da clara aplicabilidade da mediação aos conflitos familiares, é adequado assumir que a mediação se trata de uma técnica válida e obrigatória a ser designada em toda e qualquer espécie de conflito familiar?

No que se refere especificamente à submissão de conflitos familiares ao método da mediação, associações feministas levantaram o argumento de que a justiça estatal representada pelo sistema judiciário oferece garantias processuais mais concretas para a proteção dos interesses das mulheres, alegando que a mediação não leva em consideração o controle masculino presente nos conflitos conjugais nem a violência conjugal mascarada em alguns $\operatorname{casos}^{24}$.

De fato, existem situações familiares em que a aplicabilidade de métodos autocompositivos é questionável, em razão da peculiaridade do conflito existente entre as partes. Há que se aplicar um olhar específico e aprofundado para a controvérsia.

Tomemos como exemplo conflitos de natureza violenta no seio familiar, como casos de abuso sexual ou violência doméstica. Nessa situação, seria adequado exigir de uma mulher em situação de violência doméstica, que se depare de frente com o seu agressor e tente formalizar um acordo? Questionamentos como esse surgem na prática do direito de família, uma vez que o legislador, ao dispor sobre a obrigatoriedade da audiência de mediação, parece não ter se atentado para tais questões.

E o magistrado, ao se deparar com situações como essa, não pode se restringir a aplicação pura da letra da lei, devendo interpretá-la dentro das peculiaridades do caso concreto, dando uma interpretação constitucional que possa preservar a dignidade da mulher

${ }^{23}$ (CURY, Cesar Felipe. Mediação. In: ZANETI JR, Hermes; CABRAL, Trícia Navarro Xavier (Coord.). Justiça Multiportas: mediação, conciliação, arbitragem e outros meios adequados de solução de conflitos. Salvador: Juspodivm, 2018, p. 511-512).

${ }^{24}$ AVILA, Eliedite Mattos. Mediação familiar: mitos, realidades e desafios. In: WALD, Arnoldo. Arbitragem e mediação: mediação e outros modos alternativos de solução de conflitos. Coleção doutrinas essenciais, v. 6. 1. ed. São Paulo: Editora Revista dos Tribunais, 2014, p. 569. 
Revista Eletrônica de Direito Processual - REDP.

Rio de Janeiro. Ano 16. Volume 23. Número 1. Janeiro a Abril de 2022

Periódico Quadrimestral da Pós-Graduação Stricto Sensu em Direito Processual da UERJ

Patrono: José Carlos Barbosa Moreira (in mem.). ISSN 1982-7636. pp. 1266-1295

www.redp.uerj.br

em situação de violência doméstica no contexto do conflito familiar. Deve considerar, ainda, nessa interpretação, os princípios da mediação, previstos no art. $2^{\circ}$ da Lei 13.140/2015.

\section{CONFLITOS FAMILIARES E MULHERES EM SITUAÇÃO DE VIOLÊNCIA DOMÉSTICA}

No contexto dos conflitos familiares, existem alguns litígios que envolvem violência doméstica, tomando uma configuração mais complexa que merece ser explorada.

Inicialmente, é necessário compreender certos conceitos e contextualizações referentes à violência doméstica. É importante trabalhar com o conceito de papel de gênero, que consiste em um dos elementos que constitui a sexualidade humana, e diz respeito ao papel social que é esperado de cada gênero num contexto cultural ${ }^{25}$. O papel de gênero é algo imposto culturalmente conforme os ideais do patriarcado, e determina comportamentos a serem seguidos pelo gênero masculino ou feminino.

A autora Maria Berenice Dias afirma que os diferentes papeis de gênero se basearam nos valores referentes à separação entre esfera pública e privada. Dessa forma, no contexto da sociedade patriarcal, enquanto ao homem foi legitimado o espaço público de liberdade, às mulheres coube o confinamento nos limites da família e do $\operatorname{lar}^{26}$, voltado à passividade e ao resguardo no espaço privado.

Contudo, esse espaço privado/familiar que foi atribuído para o feminino comporta graves perigos, e é justamente onde se encontra a maior parte da violência contra a mulher: conforme relatório da Organização Mundial da Saúde - OMS, a maioria da violência praticada contra a mulher se dá dentro de seu próprio lar ou junto à família, e o agressor é o companheiro atual ou anterior ${ }^{27}$.

\footnotetext{
${ }^{25}$ PARAENSE, Leandro Lopes Pontes. Direito à identidade sexual: o desencaixe jurídico-social do transexual. Revista do Programa de Pós-graduação em Direito. Universidade Federal da Bahia, vol. 12, p. 133-135, 2005, p. 138.

${ }^{26}$ DIAS, Maria Berenice. A Lei Maria da Penha na Justiça. 6. Ed. rev. E atual. Salvador: Editora JusPodivm, 2019, p. 20.

${ }^{27}$ DIAS, Maria Berenice. A Lei Maria da Penha na Justiça. 6. Ed. rev. E atual. Salvador: Editora JusPodivm, 2019, p. 27.
} 
Revista Eletrônica de Direito Processual - REDP.

Rio de Janeiro. Ano 16. Volume 23. Número 1. Janeiro a Abril de 2022

Periódico Quadrimestral da Pós-Graduação Stricto Sensu em Direito Processual da UERJ

Patrono: José Carlos Barbosa Moreira (in mem.). ISSN 1982-7636. pp. 1266-1295

www.redp.uerj.br

Segundo a Organização Pan-Americana da Saúde (OPAS), a maioria dos casos é de violência cometida por parceiros, o que abrange qualquer comportamento do parceiro ou exparceiro que cause danos físicos, sexuais ou psicológicos, incluindo agressão física, coerção sexual, abuso psicológico e comportamentos de controle ${ }^{28}$. Apesar disso, esses dados não costumam ser noticiados, e a ocorrência da violência contra a mulher no ambiente privado e familiar fica velada.

Dias menciona que existe grande dificuldade para a mulher em denunciar uma pessoa com quem se reside sob o mesmo teto, que muitas vezes é o responsável pelo sustento familiar e com quem a mulher tem um vínculo afetivo e filhos em comum, o que configura, além de uma dependência financeira, uma dependência emocional em relação ao agressor ${ }^{29}$.

De fato, todas essas questões contribuem para a invisibilidade da violência doméstica e para os riscos e perigos para a mulher no espaço privado, que acabam sendo ratificados por costumes de uma sociedade patriarcal. Há inclusive certa dificuldade em se identificar e reconhecer a própria ocorrência da violência doméstica, e é também essa falta de consciência social do que configura a violência doméstica que relega a prática à invisibilidade, apesar de sua recorrência ${ }^{30}$.

No que se refere à conceituação do termo, a legislação brasileira comporta definiç̧ão trazida pela Lei Maria da Penha (Lei 11.340/2006), a qual objetiva criar "mecanismos para coibir a violência doméstica e familiar contra a mulher"31.

A Lei 11.340/2006 é uma norma de caráter preventivo, conforme se constata em seu art. $1^{\circ}$ e, ao contrário da maioria das outras legislações de mesma natureza, tem seu foco

28 OPAS. Folha informativa - violência contra as mulheres (2017). Disponível em: https://www.paho.org/bra/index.php?option=com_content\&view=article\&id=5669:folha-informativaviolencia-contra-as-mulheres\&Itemid=820. Acesso: 22/12/2019.

${ }^{29}$ DIAS, Maria Berenice. A Lei Maria da Penha na Justiça. 6. Ed. rev. E atual. Salvador: Editora JusPodivm, 2019 , p. 27.

${ }^{30}$ Idem, p. 53.

31 _. BRASIL. Lei $n^{o}$ 11.340, de 7 de Agosto de 2006. Lei Maria da Penha (2006). Disponível em: http://www.planalto.gov.br/ccivil_03/_ato2004-2006/2006/lei/111340.htm. Acesso: 30/07/2020. 
Revista Eletrônica de Direito Processual - REDP.

Rio de Janeiro. Ano 16. Volume 23. Número 1. Janeiro a Abril de 2022

Periódico Quadrimestral da Pós-Graduação Stricto Sensu em Direito Processual da UERJ

Patrono: José Carlos Barbosa Moreira (in mem.). ISSN 1982-7636. pp. 1266-1295

www.redp.uerj.br

voltado diretamente para a vítima, e não para o agressor ${ }^{32}$, justamente porque pretende colocar a mulher como protagonista da situação.

É uma lei que considera como prioridade a necessidade de garantir segurança à mulher em situação de violência doméstica, estabelecendo até mesmo a criação de Juizados de Violência Doméstica e Familiar, determinando a atuação conjunta de uma equipe multidisciplinar e especializada para tais casos, não sendo aplicável o procedimento nos termos básicos da Lei n. 9.099/95, diante da impossibilidade da violência doméstica ser equiparada a infrações de menor potencial ofensivo, em razão da dimensão social do problema $^{33}$.

$\mathrm{O}$ art. $5^{\circ}$, caput, incisos I e II da Lei Maria da Penha, definem violência doméstica e familiar contra a mulher como "qualquer ação ou omissão baseada no gênero que lhe cause morte, lesão, sofrimento físico, sexual ou psicológico e dano moral ou patrimonial" ${ }^{\text {, }}$, que pode ocorrer no âmbito da unidade doméstica, compreendida como o espaço de convívio permanente de pessoas, com ou sem vínculo familiar, bem como no âmbito da família, compreendida como a comunidade formada por indivíduos que são ou se consideram aparentados.

O mesmo dispositivo explica que a violência também se configura quando for praticada no seio de qualquer relação íntima de afeto, na qual o agressor conviva ou tenha convivido com a ofendida, independentemente de coabitação (art. $5^{\circ}$, inciso III, LMP).

Aliás, podem ser sujeitos passivos da violência doméstica não apenas esposas, como também companheiras, amantes, filhas, netas, sogra, avó ou qualquer outra parente que tenha vínculo familiar com o agressor ${ }^{35}$.

\footnotetext{
${ }^{32}$ COSTA, Bárbara Amelize; ARCELO, Adalberto Antonio Batista. Autorreconhecimento e Reconhecimento Social de Gênero como dispositivos de subjetivação e acesso às medidas protetivas da Lei $\mathrm{n}^{\circ}$ 11.340/2006. Revista de Direitos e Garantias Fundamentais, Vitória, v. 19, n. 2, p. 99-122, mai./ago., 2018, p. 108.

${ }^{33}$ CALIL, Mário Lúcio Garcez. Expectativas acerca do acesso à justiça: os Juizados de Violência Doméstica e Familiar contra a mulher na efetivação da Lei n. 11.340/2006 ("Maria da Penha"). Revista de Direitos e Garantias Fundamentais, Vitória, v., n. 13, p. 261-275, jan./jun., 2013, p. 271.

34 _. BRASIL. Lei $n^{\circ} 11.340$, de 7 de Agosto de 2006. Lei Maria da Penha (2006). Disponível em: http://www.planalto.gov.br/ccivil_03/_ato2004-2006/2006/lei/111340.htm. Acesso: 30/07/2020.

${ }_{35}$ DIAS, Maria Berenice. A Lei Maria da Penha na Justiça. 6. Ed. rev. E atual. Salvador: Editora JusPodivm, 2019, p. 70.
} 
Revista Eletrônica de Direito Processual - REDP.

Rio de Janeiro. Ano 16. Volume 23. Número 1. Janeiro a Abril de 2022

Periódico Quadrimestral da Pós-Graduação Stricto Sensu em Direito Processual da UERJ

Patrono: José Carlos Barbosa Moreira (in mem.). ISSN 1982-7636. pp. 1266-1295

www.redp.uerj.br

É de extrema importância a previsão contida no parágrafo único do art. $5^{\circ}$ da LMP, que determina que as relações pessoais entre agressor e ofendida enunciadas no artigo independem de orientação sexual, o que implica em dizer que o âmbito de incidência da lei também abarca agressões entre lésbicas, num relacionamento homoafetivo. Assim, o requisito para aplicação da lei é que a ofendida seja mulher, independentemente do gênero do agressor ${ }^{36} \cdot 37$

Portanto, exige-se a qualidade especial de ser mulher para o sujeito passivo da violência doméstica, e a referência legal ao sexo da ofendida não diz respeito ao conceito biológico do feminino, sendo que a lei não faz essa distinção, e é aplicável para quem tem identidade de gênero feminino, assegurando proteção a travestis, transexuais e transgêneros de identidade feminina, desde que mantenham relação íntima de afeto com o agressor ${ }^{38}$.

De fato, a violência doméstica é encarada como uma questão de saúde pública e de violação dos direitos humanos das mulheres ${ }^{39}$, como expressamente prevê o art. $6^{\circ}$ da Lei Maria da Penha. A condição de violência é, sobretudo, uma interface da violação de direitos humanos, uma vez que é afronta direta à dignidade da pessoa humana, princípio unificador, prioritário e central de todo o sistema normativo ${ }^{40}$.

A violência doméstica é algo que atinge a mulher de maneira multidimensional, podendo acarretar repercussões variadas, seja na vida profissional, social, na saúde física, mental, sexual e reprodutiva ${ }^{41}$. As consequências são muitas, e fora o risco de morte e os

\footnotetext{
${ }^{36}$ DIAS, Maria Berenice. A Lei Maria da Penha na Justiça. 6. Ed. rev. E atual. Salvador: Editora JusPodivm, 2019, p. 70-71.

${ }^{37}$ Maria Berenice Dias faz a ressalva de que algumas poucas decisões têm admitido a aplicação da LMP a favor do homem vítima de violência doméstica, mas a jurisprudência majoritária discorda, "considerando descabida a concessão de medida protetiva a favor de homem que alega ser vítima de violência praticada pela mulher" (DIAS, Maria Berenice. A Lei Maria da Penha na Justiça. 6. Ed. rev. E atual. Salvador: Editora JusPodivm, 2019, p. 73).

${ }^{38}$ DIAS, Maria Berenice. A Lei Maria da Penha na Justiça. 6. Ed. rev. E atual. Salvador: Editora JusPodivm, 2019, p. 71.

39 OPAS. Folha informativa - violência contra as mulheres (2017). Disponível em: https://www.paho.org/bra/index.php?option=com_content\&view=article\&id=5669:folha-informativa-

violencia-contra-as-mulheres\&Itemid=820. Acesso: 22/12/2019.

${ }^{40}$ PIOVESAN, Flávia. Direitos humanos e o direito constitucional internacional. 13. ed. São Paulo: Saraiva, 2012, p. 87.

41 OPAS. Folha informativa - violência contra as mulheres (2017). Disponível em: https://www.paho.org/bra/index.php?option=com_content\&view=article\&id=5669:folha-informativaviolencia-contra-as-mulheres\&Itemid=820. Acesso: 22/12/2019.
} 
Revista Eletrônica de Direito Processual - REDP.

Rio de Janeiro. Ano 16. Volume 23. Número 1. Janeiro a Abril de 2022

Periódico Quadrimestral da Pós-Graduação Stricto Sensu em Direito Processual da UERJ

Patrono: José Carlos Barbosa Moreira (in mem.). ISSN 1982-7636. pp. 1266-1295

www.redp.uerj.br

efeitos físicos, as sequelas psicológicas do abuso também são muito graves, pois é uma experiência que destrói a autoestima da mulher e a expõe a um risco elevado de sofrer problemas mentais, como depressão, fobia e estresse pós-traumático ${ }^{42}$.

Assim, ciente da multidimensionalidade das consequências acarretadas pela violência doméstica, vê-se que é necessário que os casos familiares que envolvam vítimas das agressões passem por um olhar diferenciado no procedimento judicial. A vulnerabilidade dessas mulheres pede que o tratamento da questão seja individualizado, e que seja dada uma interpretação constitucional ao art. 695 do CPC e ao art. 27 da Lei 13.140/15, visando à preservação da dignidade humana.

Ainda existem muitos entraves no caminho das mulheres para quebrar o silêncio, denunciar e superar a violência causada ${ }^{43}$. Por isso, mesmo as questões formais e procedimentais da lei devem passar por essa interpretação que vise, acima de tudo, preservar a segurança, autoestima e dignidade dessas mulheres. O procedimento judicial a ser adotado nessas circunstâncias deve ser aquele que proporcione maior segurança e amparo a essa mulher.

Muitas vezes existe uma certa incapacidade do poder público para lidar com a violência doméstica e para entender suas consequências e repercussões na vida da mulher agredida. Tal despreparo não ocorre somente no trato da questão na delegacia da mulher, mas também dentro do próprio poder judiciário, o que causa um sentimento de frustração e desamparo nas vítimas, bem como resulta em descrédito para o judiciário.

Nesse sentido, a aplicação de métodos autocompositivos, mais especificamente, a designação de uma audiência de mediação para casos de separação que envolvem violência doméstica, ainda que com a participação de mediadores treinados, é algo a ser repensado, pois pode ocasionar maior sofrimento a mulher e, possivelmente, uma revitimização dessa

42 DAY; TELLES; ZORATTO; AZAMBUJA; MACHADO; SILVEIRA; DEBIAGGI; REIS; CARDOSO; BLANK. Violência doméstica e suas diferentes manifestações. R. Psiquiatr. RS, 25 (suplemento 1): 9-21, abril 2003. Disponível em: http://www.scielo.br/pdf/rprs/v25s1/a03v25s1. Acesso: 22/12/2019.

${ }^{43}$ LETTIERE, Angelina; NAKANO, Ana Márcia Spanó. Violência doméstica: as possibilidades e os limites de enfrentamento. Rev. Latino-Am. Enfermagem. Nov.-dez. 2011. Disponível em: http://www.scielo.br/pdf/rlae/v19n6/pt_20.pdf. Acesso: 22/12/2019. 
Revista Eletrônica de Direito Processual - REDP.

Rio de Janeiro. Ano 16. Volume 23. Número 1. Janeiro a Abril de 2022

Periódico Quadrimestral da Pós-Graduação Stricto Sensu em Direito Processual da UERJ

Patrono: José Carlos Barbosa Moreira (in mem.). ISSN 1982-7636. pp. 1266-1295

www.redp.uerj.br

pessoa por meio da violência institucional que ela sofrerá em razão do despreparo do judiciário e da insegurança quanto à garantia de seus direitos ${ }^{44}$.

Além disso, há que se averiguar se não existe uma certa incompatibilidade entre os princípios da mediação e a situação em que se encontra uma mulher em situação de violência doméstica. Será que essa mulher estaria apta a participar desse procedimento? Existe, nessa situação, isonomia entre as partes, pressuposto para que se concretize uma autocomposição justa baseada na boa-fé?

Tais questionamentos precisam ser analisados para que se investigue a melhor maneira de amparar as mulheres em situação de violência doméstica que procuram o judiciário. Não é apenas uma questão procedimental, mas uma questão de acesso a uma justiça adequada para essas mulheres. É necessário que o poder público tenha o devido preparo para acolhê-las, e que apresente métodos adequados para tanto.

\section{4. (IN)APLICABILIDADE DA MEDIAÇÃO EM LITÍGIOS FAMILIARES QUE ENVOLVAM MULHERES EM SITUAÇÃO DE VIOLÊNCIA DOMÉSTICA}

Como já afirmado, a mediação é extremamente aplicável ao ramo do direito de família. De fato, é um procedimento que, na maioria das vezes, se mostra como uma necessidade para a resolução de muitos conflitos familiares, por isso mesmo é considerada obrigatória no procedimento judicial das ações de família.

Nesse sentido, a questão principal é investigar e discutir como os aspectos procedimentais da legislação especial para litígios familiares, mais especificamente, a imposição da obrigatoriedade da realização da mediação, deve ser interpretada de forma que proteja a vítima de violência doméstica e não lhe cause mais desconforto diante de uma

\footnotetext{
${ }^{44}$ CHAI, Cássius Guimarães; SANTOS, Jéssica Pereira dos; CHAVES, Denisson Gonçalves. Violência institucional contra a mulher: o poder judiciário, de pretenso protetor a efetivo agressor. Revista Eletrônica do Curso de Direito da UFSM, Santa Maria, RS, v. 13, n. 2, p. 640-665, ago. 2018. ISSN 1981-3694, p. 650. Disponível em: https://periodicos.ufsm.br/revistadireito/article/view/29538. Acesso: 23/12/2019.
} 
Revista Eletrônica de Direito Processual - REDP.

Rio de Janeiro. Ano 16. Volume 23. Número 1. Janeiro a Abril de 2022

Periódico Quadrimestral da Pós-Graduação Stricto Sensu em Direito Processual da UERJ

Patrono: José Carlos Barbosa Moreira (in mem.). ISSN 1982-7636. pp. 1266-1295

www.redp.uerj.br

vulnerabilidade que já existe, observando ainda os princípios do art. $2^{\circ}$ da Lei de Mediação e o acesso à justiça adequada.

Inicialmente é importante realizar uma análise principiológica da mediação, considerando os princípios fundamentais do método para averiguar sua aplicabilidade diante de conflitos familiares com violência de gênero.

Como princípios fundamentais da mediação, identificam-se aqueles expostos no art. 166 do CPC, que se aproximam do art. $1^{\circ}$ do anexo III da Resolução 125/2010 do CNJ ${ }^{45}$, e estão presentes na Lei de Mediação (Lei 13.140/15, art. $2^{\circ}$ ). São eles: independência; imparcialidade; autonomia da vontade; confidencialidade; oralidade; informalidade; decisão informada; busca do consenso; isonomia entre as partes; boa-fé; competência; respeito à ordem pública e às leis vigentes; empoderamento e validação ${ }^{46}$.

Com efeito, para os casos familiares judicializados em que há envolvimento das partes com violência doméstica, dois princípios importantes da mediação são colocados em prova, quais sejam, o princípio da autonomia da vontade e o princípio da isonomia entre as partes.

O princípio da autonomia da vontade é inerente ao próprio conceito da mediação: não há como se falar em resolução consensual do conflito sem que haja autonomia das partes justamente para possibilitar o acordo de vontades ${ }^{47}$.

Evidentemente, tal vontade não pode ser viciada, ou seja, não pode haver vício de consentimento, impedindo que a vontade seja livre e espontânea, sob pena de nulidade ${ }^{48}$. Qualquer violação desse princípio acarretaria a invalidação da autocomposição eventualmente obtida ${ }^{49}$.

\footnotetext{
${ }^{45}$ NEVES, Daniel Amorim Assumpção. Manual de direito processual civil. 11. ed. Salvador: Ed. JusPodivm, 2019, p. 69.

${ }^{46}$ PEIXOTO, Ravi. Os "princípios" da Mediação e da Conciliação: uma análise da Res. 125/2010 do CNJ, do CPC/2015 e da Lei 13.140/2015. In: ZANETI JR, Hermes; CABRAL, Trícia Navarro Xavier (Coord.). Justiça Multiportas: mediação, conciliação, arbitragem e outros meios adequados de solução de conflitos. Salvador: Juspodivm, 2018, p. 95.

${ }^{47}$ NEVES, Daniel Amorim Assumpção. Manual de direito processual civil. 11. ed. Salvador: Ed. JusPodivm, 2019, p. 71.

${ }^{48}$ NEVES, Daniel Amorim Assumpção. Manual de direito processual civil. 11. ed. Salvador: Ed. JusPodivm, 2019, p. 71.

${ }^{49}$ GORETTI, Ricardo. Mediação e acesso à justiça. Salvador: Editoria JusPodivm, 2016, p. 245.
} 
Revista Eletrônica de Direito Processual - REDP.

Rio de Janeiro. Ano 16. Volume 23. Número 1. Janeiro a Abril de 2022

Periódico Quadrimestral da Pós-Graduação Stricto Sensu em Direito Processual da UERJ

Patrono: José Carlos Barbosa Moreira (in mem.). ISSN 1982-7636. pp. 1266-1295 www.redp.uerj.br

Por sua vez, o princípio da isonomia entre as partes possui duas facetas: a isonomia procedimental, que exige que as partes sejam tratadas igualmente e tenham as mesmas oportunidades de participação no procedimento da mediação, e a isonomia material, pela qual se exige que a mediação fique restrita aos casos em que não há qualquer espécie de hipossuficiência ou vulnerabilidade de uma das partes envolvidas ${ }^{50}$.

De fato, a mediação pretende converter uma situação adversarial em um processo colaborativo e comunicativo, e isso se dá por meio do incentivo ao diálogo entre as partes ${ }^{51}$. Ocorre que, quando tratamos de casos familiares em que há violência doméstica, é certo que existe de um lado um agressor, e de outro lado, uma pessoa que está em situação de clara vulnerabilidade e que se encontra, de certa maneira, refém de seu ofensor, em posição de desigualdade e, provavelmente, sem qualquer condição emocional de dialogar frente a frente com ele.

Assim, no contexto da aplicação impositiva da mediação em conflitos familiares que envolvam violência doméstica, verificam-se certas falhas decorrentes do descumprimento de princípios fundamentais do método, que quando negligenciados, tornam a prática ineficaz e desvirtuada de seu objetivo. Vejamos.

No que se refere ao princípio da isonomia entre as partes, nota-se que a isonomia material entre os envolvidos é inexistente, uma vez que um deles está em situação incontestável de vulnerabilidade, em razão de ter sofrido diversos abusos do outro mediado. A própria Lei Maria da Penha é extremamente protetiva em relação à mulher, tendo em conta essa vulnerabilidade presumida quando se encontra em situação de violência doméstica.

Nesse sentido, numa mediação em que os participantes são um agressor e uma mulher em situação de violência doméstica, também não é possível falar em autonomia da vontade, uma vez que a vontade da mulher está completamente viciada, justamente em razão dos efeitos que a violência intrafamiliar ocasiona à mulher. O princípio da autonomia da vontade,

\footnotetext{
${ }^{50}$ NEVES, Daniel Amorim Assumpção. Manual de direito processual civil. 11. ed. Salvador: Ed. JusPodivm, 2019, p. 74.

${ }^{51}$ DIAS, Maria Berenice. Manual de direito das famílias. 12. ed. São Paulo: Editora Revista dos Tribunais, 2017, p. 75.
} 
Revista Eletrônica de Direito Processual - REDP.

Rio de Janeiro. Ano 16. Volume 23. Número 1. Janeiro a Abril de 2022

Periódico Quadrimestral da Pós-Graduação Stricto Sensu em Direito Processual da UERJ

Patrono: José Carlos Barbosa Moreira (in mem.). ISSN 1982-7636. pp. 1266-1295

www.redp.uerj.br

nesse caso, deve ser entendido em seu sentido lato, conforme ensina Fernanda Medina Pantoja. ${ }^{52}$

Contudo, como citado no capítulo anterior, as sequelas psicológicas do abuso, em regra, são muito graves, e a mulher está exposta a um risco elevado de sofrer problemas mentais e traumas. De fato, uma das características da violência doméstica é que o agressor, além de abusos físicos, submete a mulher a inúmeros abusos psicológicos que destroem sua autoestima e a colocam numa situação de medo e insegurança constante.

Diante disso, não há como se expectar a manifestação livre da vontade de uma mulher que sofreu abusos psicológicos dentro de um contexto familiar. Sua vontade, diante do agressor, em regra estará inteiramente viciada, pois ela está submetida a ele de muitas maneiras.

Não há empoderamento, tampouco autoestima ou espontaneidade daquela mulher para que ela expresse livremente sua vontade, ou seja, para que tenha a autodeterminação para escolher, conscientemente, pela celebração ou não do acordo. É uma situação subjetiva reflexo de uma violência que implica numa vulnerabilidade presumida da mulher, o que, em regra, a impede de atuar na mediação em pé de igualdade com seu agressor.

Nesse cenário, é importante falar sobre os efeitos e especificidades do trabalho de mediação em "relações permeadas por crime de gênero e família", que foram bem descritas pelas autoras Zapparolli e Krahenbuhl, quando de sua aplicação no Projeto Íntegra Gênero e Família $^{53}$. As autoras relatam, entre outras peculiaridades: desníveis de poder entre os mediados; deterioração das relações; ausência de segurança moral, psicológica e física dos mediados; impacto de eventuais processos criminais em curso; enormes entraves na

\footnotetext{
${ }^{52}$ Abarcando [...] a aceitação livre e voluntária do método consensual (e possibilidade de interrupção de seu curso a qualquer momento); a indicação do conciliador ou mediador (ou a possibilidade de oposição àquele que

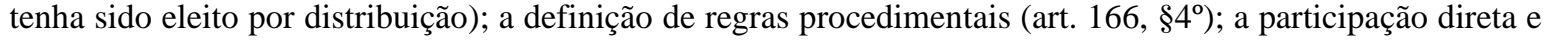
espontânea no procedimento; e, finalmente, a autodeterminação para, ao final, celebrar ou não um acordo. Permite-se, assim, que haja verdadeiro engajamento dos envolvidos, o que contribui para o cumprimento espontâneo de eventual acordo e para o desenvolvimento das aptidões pessoais de lidar com contendas posteriores. (PANTOJA, Fernanda Medina. Comentários ao novo Código de Processo Civil. Coordenação Antonio do Passo Cabral, Ronaldo Cramer. 2. ed. rev., atual. e ampl. Rio de Janeiro: Forense, 2016, p. 288).

${ }^{53}$ Apud VICENTE, Reginandréa Gomes. Ressonâncias Pessoais na mediação em crime de gênero e família. Revista do Advogado. São Paulo, v. ano XXXIV, n. 123, p. 90-95, ago., 2014, p. 91.
} 
Revista Eletrônica de Direito Processual - REDP.

Rio de Janeiro. Ano 16. Volume 23. Número 1. Janeiro a Abril de 2022

Periódico Quadrimestral da Pós-Graduação Stricto Sensu em Direito Processual da UERJ

Patrono: José Carlos Barbosa Moreira (in mem.). ISSN 1982-7636. pp. 1266-1295

www.redp.uerj.br

expressão e escuta de interesses e sentimentos; doenças psicológicas e psiquiátricas permeando o contexto de crime e violência; forte agressividade contrapondo absoluta passividade dos mediados ${ }^{54}$.

Com efeito, apesar da extensa possibilidade de aplicação da mediação para conflitos familiares, não se pode cair no engano da generalização e ignorar as subjetividades compreendidas. Existem sim casos que não são mediáveis. A aplicação da mediação depende diretamente de um diálogo justo e equilibrado entre as partes, e isso nem sempre será possível.

Analisando os efeitos da violência intrafamiliar, é possível enxergar que uma mulher em situação de violência doméstica pode se tornar atemorizada ao ponto de não conseguir expor suas opiniões e interesses ${ }^{55}$. É uma vulnerabilidade feroz.

E todo esse contexto peculiar nos leva a considerar que, apesar do legislador emitir um comando ao juiz, ao determinar a obrigatoriedade da aplicação da mediação, não permitindo discricionariedades, a mediação não pode ser considerada uma técnica válida para toda e qualquer espécie de conflito familiar, mesmo porque isso fere, como dito, princípios fundamentais do método.

É correta e compreensível a intenção de pacificação social e acesso à justiça trazida pelo legislador no texto normativo ao tornar o procedimento obrigatório, mas deve-se considerar que nos conflitos familiares que envolvam violência doméstica, a exigência legal da mediação carrega efeito reverso e contraditório, uma vez que pode configurar até mesmo um entrave ao acesso à justiça para a mulher, ao fazê-la reviver suas vulnerabilidades diante de seu agressor, violando-se a dignidade humana.

Por isso, não se pode restringir à aplicação pura da letra da lei (art. 695 do CPC e art. 27 da Lei de Mediação) no que tange à obrigatoriedade da mediação nas ações de família, devendo-se dar uma interpretação sistemática, considerando os princípios do art. $2^{\circ}$ da Lei

\footnotetext{
54 Apud VICENTE, Reginandréa Gomes. Ressonâncias Pessoais na mediação em crime de gênero e família. Revista do Advogado. São Paulo, v. ano XXXIV, n. 123, p. 90-95, ago., 2014, p. 91.

${ }^{55}$ CEZAR-FERREIRA, Verônica A. da Mota. Família, separação e mediação: uma visão psicojurídica. 4. ed. atual. e ampl. Curitiba: CRV, 2017, p. 139.
} 
Revista Eletrônica de Direito Processual - REDP.

Rio de Janeiro. Ano 16. Volume 23. Número 1. Janeiro a Abril de 2022

Periódico Quadrimestral da Pós-Graduação Stricto Sensu em Direito Processual da UERJ

Patrono: José Carlos Barbosa Moreira (in mem.). ISSN 1982-7636. pp. 1266-1295

www.redp.uerj.br

13.140/15 (especialmente, isonomia entre as partes e autonomia da vontade), para conferir uma interpretação constitucional, tendo em vista a necessidade de se manter íntegro o princípio da dignidade humana e a cláusula de acesso à justiça, no contexto dos litígios envolvendo violência doméstica em conflitos familiares.

$\mathrm{E}$ a intepretação que garante a integridade dos princípios da mediação, bem como assegura a proteção da dignidade humana e o acesso à uma justiça adequada para a mulher, é aquela que considera facultativa a mediação para esses cenários, assegurando que o tratamento destinado a essas mulheres seja digno, e que o procedimento aplicado a sua situação lhe garanta proteção e cidadania.

Há quem entenda ser possível e até necessária a aplicação da mediação mesmo em contextos familiares nos quais há violência intrafamiliar, como é o caso de Maria Coleta Oliveira et $\mathrm{al}^{56}$. As autoras explicam que os atos violentos podem ser tentativas de eliminar um conflito diante de uma dificuldade de comunicação e de acesso a outros modos de resolução da contenda ${ }^{57}$ e para solucionar a questão, propõem uma mediação familiar interdisciplinar para casos de violência intrafamiliar, concluindo que tais comportamentos podem ser modificados com práticas que permitam questionar certas noções preconcebidas e preconceituosas, e que a reflexão proporcionada por terceiros como mediadores, pode ampliar as possibilidades de conduta em situações conflituosas, auxiliando as pessoas a se libertarem da reprodução de reações impulsivas ${ }^{58}$.

De fato, a importância da desconstrução e reconstrução de conceitos e comportamentos de agressores no contexto da violência doméstica é evidente, uma vez que atitudes como esta estão impregnadas na nossa sociedade em razão de uma cultura machista e patriarcal.

\footnotetext{
${ }^{56}$ OLIVEIRA, Maria Coleta; MUSZKAT, Malvina E.; UNBEHAUM, Sandra; MUSZKAT, Susana. Mediação familiar transdisciplinar: uma metodologia de trabalho em situações de conflito de gênero. São Paulo: Summus, 2008, p. 38.

${ }^{57}$ Idem.

${ }^{58}$ Idem, p. 39.
} 
Revista Eletrônica de Direito Processual - REDP.

Rio de Janeiro. Ano 16. Volume 23. Número 1. Janeiro a Abril de 2022

Periódico Quadrimestral da Pós-Graduação Stricto Sensu em Direito Processual da UERJ

Patrono: José Carlos Barbosa Moreira (in mem.). ISSN 1982-7636. pp. 1266-1295

www.redp.uerj.br

Por isso, é essencial que existam grupos de reeducação e apoio ${ }^{59}$ para os agressores, uma vez que isso contribui diretamente para diminuir casos de reincidências ${ }^{60}$ e permite várias ressignificações culturais.

Contudo, para que isso ocorra, não se deve obrigar mulheres submetidas à violência doméstica a participar de uma sessão de mediação com seus agressores. Para ressocializar o agressor e reconstruir comportamentos, não se deve sacrificar o sofrimento e a vulnerabilidade da mulher e obrigá-la a dialogar com ele sem que ela esteja pronta ou disposta a isso.

Por outro lado, caso a mulher em situação de violência doméstica esteja em condições de manifestar expressamente seu desejo de realizar a sessão de mediação, pode-se admitir o procedimento que busca a solução consensual, devendo o juiz designar a audiência de mediação, mas determinar ao mediador que, antes de iniciar a sessão, escute primeiramente e separadamente a mulher, junto com um psicólogo, para verificar se há adequação do método na prática, considerando o cenário de violência doméstica.

Assim, na prática, o juiz, ao se deparar com uma petição inicial que indique caso de violência doméstica, não deve designar a audiência de mediação de imediato, mas antes disso, deve intimar essa mulher para que manifeste se tem ou não interesse em comparecer na sessão de mediação. Caso a manifestação seja negativa, não se realiza audiência de mediação. Caso seja positiva, deverá o magistrado designar a sessão e solicitar especial cuidado ao mediador para que antes escute separadamente a mulher em situação de violência doméstica, juntamente com um psicólogo, objetivando averiguar se estão presentes as condições necessárias para uma solução consensual justa.

Dessa forma, interpretará os artigos de forma constitucional, tendo em conta o princípio da dignidade humana e o acesso à justiça, bem como os princípios do art. $2^{\circ}$ da Lei

\footnotetext{
${ }^{59}$ No ano de 2020, a Lei 13.984/20 alterou o art. 22 da Lei Maria da Penha para estabelecer como medida protetiva de urgência a frequência do agressor a centro de educação e de reabilitação e acompanhamento psicossocial.

60 AGÊNCIA SENADO. Agressores de mulheres deverão ser reeducados, determina nova lei (2020). Disponível em: https://www12.senado.leg.br/noticias/materias/2020/04/06/agressores-de-mulheres-deveraoser-reeducados-determina-nova-lei. Acesso: 28/07/2020.
} 
Revista Eletrônica de Direito Processual - REDP.

Rio de Janeiro. Ano 16. Volume 23. Número 1. Janeiro a Abril de 2022

Periódico Quadrimestral da Pós-Graduação Stricto Sensu em Direito Processual da UERJ

Patrono: José Carlos Barbosa Moreira (in mem.). ISSN 1982-7636. pp. 1266-1295

www.redp.uerj.br

13.140/15, para entender que não é obrigatória a audiência de mediação por envolver violência intrafamiliar.

Compreendendo a audiência de mediação como facultativa nesses casos, será possível que mulheres que manifestarem seu desejo de realizar a audiência possam fazê-lo mediante o auxílio de uma equipe multidisciplinar, mas que mulheres que não possuam condições para tanto não sejam obrigadas a comparecer frente a seu agressor para formalizar um acordo com ele.

Nesse segundo cenário, entendemos que o método mais adequado para conflitos familiares que envolvam violência doméstica seria a Justiça Restaurativa, por ser um método que não busca necessariamente um acordo com o agressor, mas que objetiva principalmente que as partes construam uma solução que busque curar as vítimas, responsabilizar o ofensor e reconciliá-los ${ }^{61}$, abrangendo mais possibilidades para solucionar essa espécie de conflito familiar.

A Justiça Restaurativa é definida como um conjunto de princípios, métodos e técnicas, que visa à conscientização sobre os fatores relacionais, institucionais e sociais motivadores de conflitos e violência ${ }^{62}$. As práticas restaurativas aplicadas têm como foco a satisfação das necessidades dos envolvidos, a responsabilização ativa dos que contribuíram para a ocorrência do dano e o empoderamento da comunidade, destacando a necessidade de reparação do dano, da recomposição do tecido social rompido e as suas implicações para o futuro ${ }^{63}$.

No que tange à mediação, não há necessariamente uma parte que deva assumir a responsabilidade frente à outra por um dano causado. Por isso a justiça restaurativa seria mais adequada para os conflitos familiares que envolvam violência doméstica, uma vez que traz

\footnotetext{
${ }^{61}$ MOURA, Renata Helena Paganoto; COURA, Alexandre de Castro. Uma análise sobre a aplicação da justiça restaurativa aos conflitos civis familiares. Vitória, 2019. No prelo.

${ }^{62}$ Resolução $N^{o} 225$ de 31/05/2016 do CNJ. Disponível em: <https://atos.cnj.jus.br/atos/detalhar/2289 >. Acesso: 28 jul. 2020.

${ }^{63}$ Resolução $N^{o} 225$ de 31/05/2016 do CNJ. Disponível em: 〈https://atos.cnj.jus.br/atos/detalhar/2289 >. Acesso: 28 jul. 2020.
} 
Revista Eletrônica de Direito Processual - REDP.

Rio de Janeiro. Ano 16. Volume 23. Número 1. Janeiro a Abril de 2022

Periódico Quadrimestral da Pós-Graduação Stricto Sensu em Direito Processual da UERJ

Patrono: José Carlos Barbosa Moreira (in mem.). ISSN 1982-7636. pp. 1266-1295

www.redp.uerj.br

maior responsabilização onde há uma vítima e um agressor ${ }^{64}$ podendo proporcionar maiores chances de cura, explicação e sentido para a ofendida.

Há inclusive recomendação do CNJ para que os Tribunais de Justiça adotem práticas da Justiça Restaurativa nos casos que envolverem violência contra a mulher ${ }^{65}$. Na Carta da XI Jornada da Lei Maria da Penha, publicada em 2017, o CNJ sugere a capacitação permanente dos magistrados, das equipes multidisciplinares e dos facilitadores em Justiça Restaurativa e nas temáticas de gênero ${ }^{66}$, sendo que a técnica deve ser realizada apenas com anuência da vítima ${ }^{67}$.

Nesse cenário, a Justiça Restaurativa seria uma outra via de responsabilização, oferecendo às partes a chance de atuarem na resolução do conflito, sem que com isso se objetive a formalização de um acordo ${ }^{68}$.

De fato, no que se refere à aplicabilidade da mediação para conflitos familiares onde há violência doméstica, entendemos que esta não poderá ser considerada obrigatória, não se mostrando razoável a imposição da sessão de mediação à mulher, mesmo porque, como dito, tal imposição afronta princípios fundamentais da própria mediação, bem como o princípio da dignidade humana e do acesso à justiça.

Assim, é necessária uma interpretação constitucional do art. 27 da Lei de Mediação e do art. 695, caput do CPC, para que estes sejam compreendidos de forma a preservar a dignidade humana das mulheres ofendidas, seu acesso a uma justiça adequada e os princípios da mediação, ao considerar a audiência de mediação facultativa nesses cenários, sendo a

\footnotetext{
${ }^{64}$ MOURA, Renata Helena Paganoto; COURA, Alexandre de Castro. Uma análise sobre a aplicação da justiça restaurativa aos conflitos civis familiares. Vitória, 2019. No prelo.

${ }^{65}$ CNJ. Justiça Restaurativa deve ser usada em caso de violência doméstica (2017). Disponível em: <https://www.cnj.jus.br/justica-restaurativa-deve-ser-usada-para-resolver-casos-de-violencia-domestica/>. Acesso: 28 jul. 2020.

66 CNJ. CARTA DA XI JORNADA DA LEI MARIA DA PENHA (2017). Disponível em <https://www.cnj.jus.br/wpcontent/uploads/2017/08/706fdfd1d015b74a169c11d9b56810cb.pdf>. Acesso: 28 jul. 2020.

${ }^{67}$ Idem.

${ }^{68}$ LUZ, Ilana Martins. Justiça Restaurativa e Mediação Vítima-Ofensor no Sistema Criminal. In: ZANETI JR, Hermes; CABRAL, Trícia Navarro Xavier (Coord.). Justiça Multiportas: mediação, conciliação, arbitragem e outros meios adequados de solução de conflitos. Salvador: Juspodivm, 2018, p. 654.
} 
Revista Eletrônica de Direito Processual - REDP.

Rio de Janeiro. Ano 16. Volume 23. Número 1. Janeiro a Abril de 2022

Periódico Quadrimestral da Pós-Graduação Stricto Sensu em Direito Processual da UERJ

Patrono: José Carlos Barbosa Moreira (in mem.). ISSN 1982-7636. pp. 1266-1295

www.redp.uerj.br

Justiça Restaurativa apresentada como outra via de responsabilização, capaz de oferecer respostas, explicações e uma possível cura para mulheres em situação de violência doméstica.

\section{CONSIDERAÇÕES FINAIS}

Por meio da análise de uma nova concepção de justiça multiportas, a utilização de métodos adequados de resolução de conflitos, que apresentam uma outra perspectiva fora do procedimento burocrático do processo judicial, proporciona uma ampliação do acesso à justiça, uma vez que compreende que este não é apenas o acesso ao Judiciário, mas é o acesso a uma ordem jurídica justa ${ }^{69}$.

Assim, o acesso à justiça se configura por meio do alcance de técnicas e procedimentos adequados para a solução do conflito, que possam satisfatoriamente sanar a demanda e garantir o cumprimento do direito material, o que é assegurado através da prática de métodos adequados de resolução de conflitos, como a mediação.

Buscou-se compreender a mediação como o método de resolução de conflitos utilizado quando há uma relação continuada e multidimensional entre as partes, se tratando de um procedimento mais complexo, que exige do mediador maior sensibilidade, bem como uma compreensão holística do conflito, para incentivar o diálogo entre as partes.

Justamente em razão das características supramencionadas, reconheceu-se a mediação como técnica essencial, de terreno fértil, para ser aplicada aos conflitos familiares, uma vez que contribuirá para o desenvolvimento de uma comunicação democrática e humana entre os envolvidos, objetivando a construção de uma solução conjunta ${ }^{70}$.

Contudo, não obstante a legislação contemple previsão no sentido de tornar obrigatória a realização da sessão de mediação no procedimento cível, no que se refere à

\footnotetext{
${ }^{69}$ WATANABE, Kazuo. Acesso à justiça e solução pacífica dos conflitos de interesses. In: ZANETI JR, Hermes; CABRAL, Trícia Navarro Xavier (Coord.). Justiça Multiportas: mediação, conciliação, arbitragem e outros meios adequados de solução de conflitos. Salvador: Juspodivm, 2018, p. 840.

${ }^{70}$ AVILA, Eliedite Mattos. Mediação familiar: mitos, realidades e desafios. In: WALD, Arnoldo. Arbitragem e mediação: mediação e outros modos alternativos de solução de conflitos. Coleção doutrinas essenciais, v. 6. 1. ed. São Paulo: Editora Revista dos Tribunais, 2014, p. 570.
} 
Revista Eletrônica de Direito Processual - REDP.

Rio de Janeiro. Ano 16. Volume 23. Número 1. Janeiro a Abril de 2022

Periódico Quadrimestral da Pós-Graduação Stricto Sensu em Direito Processual da UERJ

Patrono: José Carlos Barbosa Moreira (in mem.). ISSN 1982-7636. pp. 1266-1295

www.redp.uerj.br

imposição do método em conflitos familiares que envolvam mulheres em situação de violência doméstica, a partir do estudo de conceitos, contextos e efeitos da violência intrafamiliar e dos princípios fundamentais da mediação, concluiu-se por não ser possível a imposição da audiência de mediação nesses conflitos familiares, uma vez que há grande vulnerabilidade de um dos mediados, o que impede a concretização da isonomia entre as partes e da autonomia da vontade, requisitos essenciais para se realizar a sessão de mediação.

Foi possível afirmar que acordos formalizados por meio de uma audiência de mediação obrigatória nesses contextos familiares violentos nasceriam com vício de consentimento, tendo em vista que a mulher mediada está submetida a seu agressor de diversas formas, por ter sofrido abusos psicológicos/físicos que desmantelaram sua autoestima e independência necessárias para que ela pudesse expor suas opiniões e interesses $^{71}$, o que tornaria nulo o procedimento ${ }^{72}$.

Assim, é necessária a realização de uma interpretação constitucional do art. 27 da Lei de Mediação e do art. 695 do CPC, para que a mediação seja considerada facultativa nesse cenário, de modo a preservar a dignidade humana da mulher em situação de violência doméstica, bem como garantir sua integridade física e psíquica, seu direito à saúde, segurança e, acima de tudo, seu direito à vida.

Por fim, a Justiça Restaurativa se mostra como outra via de responsabilização, que apresenta às partes a chance de atuarem na resolução do conflito ${ }^{73}$, sem que com isso se objetive a formalização de um acordo, método que, portanto, seria ideal para as mulheres em situação de violência doméstica que não possuem condições de realizar uma sessão de mediação com seu agressor.

\section{REFERÊNCIAS:}

\footnotetext{
${ }^{71}$ CEZAR-FERREIRA, Verônica A. da Mota. Família, separação e mediação: uma visão psicojurídica. 4. ed. atual. e ampl. Curitiba: CRV, 2017, p. 139.

72 NEVES, Daniel Amorim Assumpção. Manual de direito processual civil. 11. ed. Salvador: Ed. JusPodivm, 2019, p. 71.

${ }^{73}$ LUZ, Ilana Martins. Justiça Restaurativa e Mediação Vítima-Ofensor no Sistema Criminal. In: ZANETI JR, Hermes; CABRAL, Trícia Navarro Xavier (Coord.). Justiça Multiportas: mediação, conciliação, arbitragem e outros meios adequados de solução de conflitos. Salvador: Juspodivm, 2018, p. 654.
} 
. BRASIL. Lei n $n^{\circ} 13.105$, de 16 de Março de 2015. Código de Processo Civil (2015). Disponível em: http://www.planalto.gov.br/ccivil_03/_ato20152018/2015/lei/113105.htm.

BRASIL. Lei n ${ }^{\circ}$ 13.140, de 26 de Junho de 2015. Lei de Mediação (2015). Disponível em: http://www.planalto.gov.br/ccivil_03/_ato2015-2018/2015/lei/113140.htm.

. BRASIL. Lei $n^{\circ}$ 11.340, de 7 de Agosto de 2006. Lei Maria da Penha (2006). Disponível em: http://www.planalto.gov.br/ccivil_03/_ato20042006/2006/lei/111340.htm.

AGÊNCIA SENADO. Agressores de mulheres deverão ser reeducados, determina nova lei (2020). Disponível em: https://www12.senado.leg.br/noticias/materias/2020/04/06/agressores-de-mulheresdeverao-ser-reeducados-determina-nova-lei.

ALMEIDA, Guilherme Assis de. Mediação e o Reconhecimento da Pessoa. Revista do Advogado. São Paulo, v. ano XXXIV, n. 123, p. 19-23, ago., 2014.

AVILA, Eliedite Mattos. Mediação familiar: mitos, realidades e desafios. In: WALD, Arnoldo. Arbitragem e mediação: mediação e outros modos alternativos de solução de conflitos. Coleção doutrinas essenciais, v. 6. 1. ed. São Paulo: Editora Revista dos Tribunais, 2014.

CABRAL, Trícia Navarro Xavier. Análise comparativa entre a Lei de Mediação e o CPC/2015. In: ZANETI JR, Hermes; CABRAL, Trícia Navarro Xavier (Coord.). Justiça Multiportas: mediação, conciliação, arbitragem e outros meios adequados de solução de conflitos. Salvador: Juspodivm, 2018.

CALIL, Mário Lúcio Garcez. Expectativas acerca do acesso à justiça: os Juizados de Violência Doméstica e Familiar contra a mulher na efetivação da Lei n. 11.340/2006 ("Maria da Penha"). Revista de Direitos e Garantias Fundamentais, Vitória, v., n. 13, p. 261-275, jan./jun., 2013.

CEZAR-FERREIRA, Verônica A. da Mota. Família, separação e mediação: uma visão psicojurídica. 4. ed. atual. e ampl. Curitiba: CRV, 2017. 
CHAI, Cássius Guimarães; SANTOS, Jéssica Pereira dos; CHAVES, Denisson Gonçalves. Violência institucional contra a mulher: o poder judiciário, de pretenso protetor a efetivo agressor. Revista Eletrônica do Curso de Direito da UFSM, Santa Maria, RS, v. 13, n. 2, p. 640-665, ago. 2018. ISSN 1981-3694. Disponível em: https://periodicos.ufsm.br/revistadireito/article/view/29538.

COSTA, Bárbara Amelize; ARCELO, Adalberto Antonio Batista. Autorreconhecimento e Reconhecimento Social de Gênero como dispositivos de subjetivação e acesso às medidas protetivas da Lei $\mathrm{n}^{\mathrm{o}}$ 11.340/2006. Revista de Direitos e Garantias Fundamentais, Vitória, v. 19, n. 2, p. 99-122, mai./ago., 2018.

CURY, Cesar Felipe. Mediação. In: ZANETI JR, Hermes; CABRAL, Trícia Navarro Xavier (Coord.). Justiça Multiportas: mediação, conciliação, arbitragem e outros meios adequados de solução de conflitos. Salvador: Juspodivm, 2018.

CNJ. CARTA DA XI JORNADA DA LEI MARIA DA PENHA (2017). Disponível em https://www.cnj.jus.br/wpcontent/uploads/2017/08/706fdfd1d015b74a169c11d9b56 810cb.pdf.

CNJ. Justiça Restaurativa deve ser usada em caso de violência doméstica (2017). Disponível em: https://www.cnj.jus.br/justica-restaurativa-deve-ser-usada-para-resolver-casosde-violencia-domestica/.

DAY; TELLES; ZORATTO; AZAMBUJA; MACHADO; SILVEIRA; DEBIAGGI; REIS; CARDOSO; BLANK. Violência doméstica e suas diferentes manifestações. $R$. Psiquiatr. RS, 25 (suplemento 1): 9-21, abril 2003. Disponível em: http://www.scielo.br/pdf/rprs/v25s1/a03v25s1.

DIAS, Maria Berenice. Manual de direito das famílias. 12. ed. São Paulo: Editora Revista dos Tribunais, 2017.

DIAS, Maria Berenice. A Lei Maria da Penha na Justiça. 6. Ed. rev. E atual. Salvador: Editora JusPodivm, 2019.

DIDIER JR, Fredie; ZANETI JR, Hermes. Justiça Multiportas e tutela adequada em litígios complexos: a autocomposição e os direitos coletivos. In: ZANETI JR, Hermes; CABRAL, Trícia Navarro Xavier (Coord.). Justiça Multiportas: mediação, 
Revista Eletrônica de Direito Processual - REDP.

Rio de Janeiro. Ano 16. Volume 23. Número 1. Janeiro a Abril de 2022

Periódico Quadrimestral da Pós-Graduação Stricto Sensu em Direito Processual da UERJ

Patrono: José Carlos Barbosa Moreira (in mem.). ISSN 1982-7636. pp. 1266-1295

www.redp.uerj.br

conciliação, arbitragem e outros meios adequados de solução de conflitos. Salvador: Juspodivm, 2018.

FISCHER, Roger; URY, William; PATTON, Bruce. Como chegar ao sim: negociação de acordos sem concessões. $2^{\mathrm{a}}$ ed. rev. e ampl. Rio de Janeiro: Imago Ed., 1994.

GORETTI, Ricardo. Mediação e acesso à justiça. Salvador: Editoria JusPodivm, 2016.

LETTIERE, Angelina; NAKANO, Ana Márcia Spanó. Violência doméstica: as possibilidades e os limites de enfrentamento. Rev. Latino-Am. Enfermagem. Nov.dez. 2011. Disponível em: http://www.scielo.br/pdf/rlae/v19n6/pt_20.pdf.

LUZ, Ilana Martins. Justiça Restaurativa e Mediação Vítima-Ofensor no Sistema Criminal. In: ZANETI JR, Hermes; CABRAL, Trícia Navarro Xavier (Coord.). Justiça Multiportas: mediação, conciliação, arbitragem e outros meios adequados de solução de conflitos. Salvador: Juspodivm, 2018.

MANCUSO, Rodolfo de Camargo. A resolução dos conflitos e a função judicial no contemporâneo Estado de Direito. São Paulo: Editora Revista dos Tribunais, 2009.

MOURA, Renata Helena Paganoto; COURA, Alexandre de Castro. Uma análise sobre a aplicação da justiça restaurativa aos conflitos civis familiares. Vitória, 2019. No prelo.

NALINI, José Renato. É urgente construir alternativas à justiça. In: ZANETI JR, Hermes; CABRAL, Trícia Navarro Xavier (Coord.). Justiça Multiportas: mediação, conciliação, arbitragem e outros meios adequados de solução de conflitos. Salvador: Juspodivm, 2018.

NEVES, Daniel Amorim Assumpção. Manual de direito processual civil. 11. ed. Salvador: Ed. JusPodivm, 2019.

OLIVEIRA, Maria Coleta; MUSZKAT, Malvina E.; UNBEHAUM, Sandra; MUSZKAT, Susana. Mediação familiar transdisciplinar: uma metodologia de trabalho em situações de conflito de gênero. São Paulo: Summus, 2008.

OPAS. Folha informativa - violência contra as mulheres (2017). Disponível em: https://www.paho.org/bra/index.php?option=com_content\&view=article\&id=5669:f olha-informativa-violencia-contra-as-mulheres \&Itemid=820. 
Revista Eletrônica de Direito Processual - REDP.

Rio de Janeiro. Ano 16. Volume 23. Número 1. Janeiro a Abril de 2022

Periódico Quadrimestral da Pós-Graduação Stricto Sensu em Direito Processual da UERJ

Patrono: José Carlos Barbosa Moreira (in mem.). ISSN 1982-7636. pp. 1266-1295

www.redp.uerj.br

PANTOJA, Fernanda Medina. Comentários ao novo Código de Processo Civil. Coordenação Antonio do Passo Cabral, Ronaldo Cramer. 2. ed. rev., atual. e ampl. Rio de Janeiro: Forense, 2016.

PARAENSE, Leandro Lopes Pontes. Direito à identidade sexual: o desencaixe jurídicosocial do transexual. Revista do Programa de Pós-graduação em Direito. Universidade Federal da Bahia, vol. 12, 2005, p. 133-135.

PEIXOTO, Ravi. Os "princípios" da Mediação e da Conciliação: uma análise da Res. 125/2010 do CNJ, do CPC/2015 e da Lei 13.140/2015. In: ZANETI JR, Hermes; CABRAL, Trícia Navarro Xavier (Coord.). Justiça Multiportas: mediação, conciliação, arbitragem e outros meios adequados de solução de conflitos. Salvador: Juspodivm, 2018.

PIOVESAN, Flávia. Direitos humanos e o direito constitucional internacional. 13. ed. São Paulo: Saraiva, 2012.

Resolução $\quad N^{o} \quad 225$ de 31/05/2016 do CNJ. Disponível em: https://atos.cnj.jus.br/atos/detalhar/2289.

VICENTE, Reginandréa Gomes. Ressonâncias Pessoais na mediação em crime de gênero e família. Revista do Advogado. São Paulo, v. ano XXXIV, n. 123, p. 90-95, ago., 2014.

WATANABE, Kazuo. Acesso à justiça e solução pacífica dos conflitos de interesses. In: ZANETI JR, Hermes; CABRAL, Trícia Navarro Xavier (Coord.). Justiça Multiportas: mediação, conciliação, arbitragem e outros meios adequados de solução de conflitos. Salvador: Juspodivm, 2018. 